\title{
Clinical Studies in Stem Cells Transplantation for Stroke: A Review
}

\author{
Anna Bersano ${ }^{1}$, Elena Ballabio ${ }^{1}$, Silvia Lanfranconi ${ }^{1}$, Giorgio B. Boncoraglio ${ }^{2}$, Stefania Corti ${ }^{1}$, \\ Federica Locatelli ${ }^{3}$, Pierluigi Baron ${ }^{1}$, Nereo Bresolin ${ }^{1}$, Eugenio Parati ${ }^{2}$ and Livia Candelise ${ }^{1, *}$
}

\author{
${ }^{I}$ Department of Neurological Sciences (Neurology Unit), Milan University, Ospedale Maggiore Policlinico, Milan, It- \\ aly; ${ }^{2}$ Cerebrovascular Diseases Unit, Fondazione IRCCS Istituto Neurologico "C. Besta”, Milan, Italy; ${ }^{3}$ Istituto la Nos- \\ tra Famiglia E.Medea, Bosisio Parini, LC, Italy
}

\begin{abstract}
Stroke is a significant cause of long-term disability. Currently, once damage from a stroke is established little can be done to recover lost function. Cell transplantation emerged as possible alternative therapy, on the basis of animal studies showing that cells transplanted into the brain not only survive but also lead to functional improvement in different neurodegenerative diseases. Stem cells have been tested in stroke patients as a possible treatment option. While initially stem cells seemed to work by a "cell replacement" mechanism, it is emerging that cell therapy works mostly by providing trophic support to the injured tissue and brain, fostering both neurogenesis and angiogenesis. This review summarizes clinical studies on stem cell transplantation in stroke patients to evaluate the safety, feasibility of administration and tolerability of this experimental treatment.
\end{abstract}

At present there is little evidence to assess the applicability of this treatment in stroke patients and well designed clinical trials are necessary to evaluate safety and toxicity as well as optimal cell type, route and time of delivery.

Keywords: Stem cells, cell transplantation, stroke, cerebrovascular disease, clinical studies, human.

\section{INTRODUCTION}

Stroke is the third leading cause of death and disability among the adult population in developed countries. Despite immediate medical attention and some interventions during the acute phase of stroke such as thrombolytic agents [1], many patients still have persistent deficits. In addition to therapies addressed to improve cerebral blood flow, there has been increasing emphasis on neuroprotective strategies, but at the present time no cytoprotective agents have been proven to be effective [2-4]. Once the damage from a stroke event has maximized, little can be done to restore premorbid function. Thus, there is a compelling need to develop treatments aimed at reducing neurological deficits. In experimental stroke the injured brain shows features that seem recapitulate the CNS development as suggested by the observed induction of an array of genes and proteins last seen in the embryonic and developing brain [5]. This observation suggests that injured brain is primed for potentiation of neurorestorative processes. There are multiple strategies to promote these restorative processes, including cell-based and pharmacologic therapies [6-14]. Data from animal models support the safety and effectiveness of stem cell transplantation to enhance neurological recovery from severe ischaemic stroke. Cells transplanted to the brain not only survive, but also lead to functional improvement in different neurodegenerative diseases models [15-17].

On this observation stem cell transplantation could represent a potential therapeutic strategy for some neurological

*Address correspondence to this author at the Department of Neurological Sciences, Milan University, Via Francesco Sforza, 35, 20122 Milan, Italy; Tel: +39 (0)2 55033830; Fax: +39 (0)2 50320430; E-mail: prosit@ unimi.it disorders including cerebrovascular diseases. Cell-based therapies, that are under investigation so far, include a variety of cells such as bone marrow mesenchymal, cord blood, fetal and embryonic cells [18, 19]. Transplanted cells are believed to give some benefits not only directly by cell replacement in damaged tissues, but also through trophic, neuroprotective and immunomodulatory effects. It is supposed that grafted cells, through secretion of trophic factors, preserve existing host cells and connections, enhance synaptic activity and provide a bridge for host axonal regeneration [20]. It is believed that they also amplify endogenous processes of brain plasticity, including neurogenesis and angiogenesis that may contribute to neurological function improvement after stroke. This review summarizes clinical studies on stem cell transplantation in stroke patients to evaluate safety, feasibility of administration and tolerability of this experimental therapy.

\section{CLINICAL TRIALS FOR STROKE PATIENTS}

Different stem cells sources such as embryonic stem cells (ESCs), neuroepithelial or teratocarcinoma cell lines, neural stem cells (NSCs) from the embryonic or adult brain or stem cells from other tissues (e.g. bone marrow) are under investigation in stroke transplantation, by using different methods for their isolation and culture.

Following the promising results in animal models, few clinical trials have been implemented.

To date, 7 small clinical trials in humans evaluated the safety and the effect of different stem cells on stroke outcome (Table 1) [21-27]. 
Table 1. Clinical Studies of Stem-Cell Transplantation

\begin{tabular}{|c|c|c|c|c|c|c|c|}
\hline $\begin{array}{c}\text { Study } \\
\text { Reference }\end{array}$ & $\begin{array}{l}\text { Type of } \\
\text { Study }\end{array}$ & Sample & $\begin{array}{c}\text { Type of Stem } \\
\text { Cells }\end{array}$ & Mode of Delivery & Type of Stroke & $\begin{array}{c}\text { Mean Time } \\
\text { Since Onset of } \\
\text { Stroke }\end{array}$ & Results \\
\hline $\begin{array}{l}\text { Kondziolka } \text { et } \\
\text { al., } 2000\end{array}$ & Phase I trial & 12 & NT2N cells ${ }^{*}$ & $\begin{array}{l}\text { Stereotactic implan- } \\
\text { tation }\end{array}$ & $\begin{array}{l}\text { Ischemic involving } \\
\text { basal ganglia ( } 8 \text { cases) } \\
\text { or basal ganglia and } \\
\text { cerebral cortex ( } 4 \text { cases) }\end{array}$ & 27 months & $\begin{array}{l}\text { No cell-related adverse } \\
\text { effects } 5 \text { years after cell } \\
\text { transplantation }\end{array}$ \\
\hline $\begin{array}{l}\text { Kondziolka et } \\
\text { al., } 2005\end{array}$ & $\begin{array}{l}\text { Phase II } \\
\text { randomized } \\
\text { trial }\end{array}$ & 18 & NT2N cells ${ }^{*}$ & $\begin{array}{l}\text { Stereotactic implan- } \\
\text { tation }\end{array}$ & $\begin{array}{l}\text { Ischemic }(9 \text { cases }) \text { or } \\
\text { hemorrhagic }(9 \text { cases, } \\
\text { involving basal ganglia } \\
\text { but no motor cortex }\end{array}$ & 3.5 years & $\begin{array}{l}\text { A single seizure the day } \\
\text { after the surgery and a } \\
\text { subdural hematoma } 1 \\
\text { month after transplanta- } \\
\text { tion. No evidence of a } \\
\text { significant benefit in } \\
\text { motor function but it } \\
\text { indicate the safety and the } \\
\text { feasibility of neuron } \\
\text { transplantation }\end{array}$ \\
\hline $\begin{array}{l}\text { Savitz et al., } \\
2005\end{array}$ & Phase I trial & 5 & $\begin{array}{l}\text { Fetal Porcine } \\
\text { cells }\end{array}$ & $\begin{array}{l}\text { Stereotactic implan- } \\
\text { tation }\end{array}$ & $\begin{array}{l}\text { Ischemic involving the } \\
\text { striatum }\end{array}$ & 4.9 years & $\begin{array}{l}\text { The study was termined } \\
\text { by the FDA }{ }^{\S} \text { after } 2 \text { pa- } \\
\text { tients developed adverse } \\
\text { events }\end{array}$ \\
\hline $\begin{array}{l}\text { Bang et al., } \\
2005\end{array}$ & $\begin{array}{l}\text { Phase I e II } \\
\text { randomized } \\
\text { trial }\end{array}$ & $\begin{array}{l}30 \\
(5 \\
\text { cases })\end{array}$ & $\mathrm{MSC}^{+}$ & $\begin{array}{l}\text { Intravenous injec- } \\
\text { tion }\end{array}$ & $\begin{array}{l}\text { Ischemic in middle } \\
\text { cerebral artery territory }\end{array}$ & 46.6 days & $\begin{array}{l}\text { No cell-related adverse } \\
\text { effects } 1 \text { year after cell } \\
\text { transplantation }\end{array}$ \\
\hline $\begin{array}{l}\text { Rabinovich et } \\
\text { al. } 2005\end{array}$ & Case series & 10 & $\begin{array}{l}\text { Human Fetal } \\
\text { cells }\end{array}$ & $\begin{array}{l}\text { Subarachnoidal } \\
\text { injection }\end{array}$ & $\begin{array}{l}\text { Ischemic ( } 7 \text { cases) or } \\
\text { hemorrhagic ( } 3 \text { cases) } \\
\text { involving the middle } \\
\text { cerebral artery territory }\end{array}$ & 12.1 months & $\begin{array}{l}\text { Some patients developed } \\
\text { fever and meningism } 48 \\
\text { hours after transplantation }\end{array}$ \\
\hline $\begin{array}{l}\text { Man et al. } \\
2006\end{array}$ & Case series & 10 & HUCBSC & $\begin{array}{l}\text { Superficial vein of } \\
\text { back of the hand }\end{array}$ & $\begin{array}{l}\text { Ischemic ( } 6 \text { cases) or } \\
\text { hemorrhagic ( } 4 \text { cases) }\end{array}$ & 23.5 months & $\begin{array}{l}\text { No side effects (immuno- } \\
\text { suppressive treatment was } \\
\text { not used) }\end{array}$ \\
\hline $\begin{array}{l}\text { Yang et al. } \\
2005\end{array}$ & Case series & 26 & $\begin{array}{l}\text { Embryonic } \\
\text { neural stem cells }\end{array}$ & $\begin{array}{l}\text { Microinvasive intra- } \\
\text { lesion injection in } 3 \\
\text { acute patients with } \\
\text { haematoma. } \\
\text { Subarachnoid injec- } \\
\text { tion in the remaining } \\
\text { patients }\end{array}$ & $\begin{array}{l}\text { Ischemic ( } 15 \text { cases }) \text { or } \\
\text { hemorrhagic ( } 11 \text { cases })\end{array}$ & $\begin{array}{l}3 \text { acute hemor- } \\
\text { rhagic strokes } \\
\text { and } 23 \text { chronic } \\
\text { ( } 4.2 \text { years })\end{array}$ & $\begin{array}{l}\text { Transient fever in } 4 \text { pa- } \\
\text { tients }\end{array}$ \\
\hline
\end{tabular}

*Immortalized NT2 cell line derived from a human teratocarcinoma. $\S \mathrm{FDA}=$ Federal Drug Administration.

+ mesenchymal stem cells.

In 1998, the US Food and Drug Administration (FDA), on the basis of data from experimental studies, approved a small phase I open-label trial in which neuroteratocarcinoma $(\mathrm{NT} 2 \mathrm{~N})$ cells were transplanted in stroke patients [21]. In animal models, immortalized cell line NT2 (derived from a human testicular germ cell tumor) shows an exclusive commitment to a neural lineage when exposed to retinoic acid (RA) [28, 29]. Grafted NT2N cells into adult mice brain have been shown in several studies to elaborate processes within 3 weeks reaching terminal differentiation by 6-8 weeks and to survive up to 14 months without reverting to a neoplastic state [30]. They express surface markers and cy- toskeletal proteins characteristics of mature neurons [21]. Transplanted cells also release neurotransmitters and elaborate typical neuronal proteins. Intrastriatal transplantation 1 month after middle cerebral artery (MCA) occlusion, followed by immunosuppression with cyclosporin, led to a significant improvement at passive avoidance test (a test of learning behavior retention time) and elevated body swing test compared to ischemic animals that received rat fetal cerebellar grafts, growth medium alone, or cyclosporin alone [30]. The ready constant availability of cryopreserved pure neurons has made the NT2N cells an attractive implant source. 
The 12 recruited patients experienced a basal ganglia stroke 6 months to 4.5 years before implantation and received, on the base of preclinical data, doses from 2 to 6 million cells. An immunosuppressive treatment with cyclosporin was performed for 8 weeks. Five years after surgery there were no adverse events related to the implant. One patient had a single seizure 6 months after surgery which was thought to be related to incident stroke and not to surgery, implantation or prior cyclosporin use. Subsequent medical problems have been attributed to cardiovascular risk factors and advancing age. Autopsy on 1 patient, who died for myocardial infarction 27 months after the surgical procedure, revealed a population of immunoreactive grafted cells without signs of inflammation, infection or neoplasia, suggesting that the grafts can safely survive, without continued immunosuppression [31].

Moreover, positron emission tomography (PET) scanning at 6 months showed high uptake of F-18 fluorodeoxyglucose at transplant site in 6 patients, suggesting cellular activity that could be due to graft survival, but also attributable to inflammatory response [32].

Although this trial was not designed to evaluate efficacy, 6 patients presented an improvement in the European Stroke Scale (ESS) scores at 24 weeks and these data, in some patients, correlated with increased PET metabolic activity [21].

In the following years Kondziolka et al. [22] presented a phase II randomized open-label trial to test safety, feasibility and effectiveness of NT2N cell transplantation for stroke. Eighteen patients, aged 18-75 years, with stable deficit 1 to 6 years after ischemic or hemorrhagic basal ganglia stroke, were randomized to receive either 5 or 10 million implanted cells ( 7 patients per group) or to serve as non-surgical control group (4 patients). Patients received cyclosporin A for 1 week before and 6 months after surgery. All recruited subjects underwent to a stroke rehabilitation program. One patient experienced a single seizure the day after the surgery and another one developed a subdural hematoma evacuated 1 month after transplantation. No cell-related adverse serological and imaging events were observed by serial evaluations. The primary outcome was ESS motor score at 6 months. Secondary end points included Fugl-Meyer Stroke Assessment, Action Reach Arm Test, Stroke Impact Scale and results of comprehensive cognitive testing. In transplanted patients the ESS motor score did not significantly differ from controls, instead some secondary outcome measures such as the Stroke Impact Scale, Everyday Memory scores and Action Reach Arm Test were significantly improved in the treatment arm of the study [22]. Four transplanted subjects who had stroke in non dominant hemisphere showed marked improvement on the Rey Complex figure test, reflecting that cell transplants can restore some cognitive functions such as planning and organization abilities [33]. This study demonstrated the feasibility of neuronal cells implantation procedures in human.

Savitz and colleagues [23] stereotactically injected fetal porcine cells into 5 patients 25 to 52 years old who experienced basal ganglia stroke between 1.5 and 10 years before. Ten deposits of 100000 cells $/ \mathrm{mm}^{3}$ were made for each trajectory to total $10^{6} \times 10^{6}$ cells per needle tract. The study was stopped by the FDA because 2 patients developed adverse events. One patient had a worsening of a motor deficit worsening weeks after intervention due to cerebral infarct detected by MRI and the second one developed seizures 1 week after transplantation. In this last patient the cerebral MRI showed a ring enhancing lesion subjacent to the site of the first hole where no implantation occurred. At 4 years of clinical follow-up 2 patients showed functional improvement but none of patients showed improvement on the modified Rankin scale.

Bang and colleagues [24] presented a randomized controlled phase I/II clinical trial of mesenchymal stem cell (MSCs) transplantation in massive cortical infarct of the middle cerebral artery (MCA) territory. The aim of the study was to verify feasibility, efficacy and safety of cell replacement therapy using cultured autologous MSCs, evaluating post implantation clinical outcome and neuroradiological features. Thirty patients (30-75 years old), within 7 days of stroke, were randomly allocated to receive intravenous infusion of autologous MSCs (5 patients) or no intervention (25 patients). No cell-related adverse effects were reported. At 1 year follow-up, Barthel index and modified Rankin score showed a non-significant trend toward improved scores in patients treated with MSCs. Also, changes in NIHSS scores were not substantial.

The authors conclude that MSCs transplantation is safe and feasible, even if they underline the need of implementation of double-blind large cohort studies to confirm their promising results.

Rabinovich et al. [25] injected human fetal cells into the subarachnoid space of 10 patients aged 35-56 years between 4 and 24 months after their ischemic or haemorrhagic stroke of MCA territory. Humal fetal cells were obtained from human fetuses after spontaneous or prostaglandin-induced abortion. Some patients developed fever and meningism within $48 \mathrm{~h}$ after transplantation. The control group was chosen retrospectively and the outcome measures were not clearly described. These shortcomings preclude any conclusion about efficacy.

Man et al. in 2006 [26] published 1 study on 10 Chinese patients with stroke sequelae (6 ischemic and 4 hemorrhagic) who were treated, after a time ranging from 3 months- 7 years (mean 23.5 months), with 6 portions $\left(1 \times 10^{8}\right.$ cells/portion) of human umbilical cord blood stem cells (HUCBSC) i.v. The study was designed to evaluate the improvement of both neurological function and daily living activity through a pretransplantation and a 3 months follow-up evaluation using neurological function deficiency (NFD) test, Fugl-Meyer Assessment (FMA) score, ADL and Barthel Index. No side effects were reported and, despite immunosuppressive treatment were not used during the whole procedure, no immunological or allergic reaction was observed. Since FMA and BI were significantly higher at 3 months follow-up, the authors conclude that this procedure is easy feasible and effective. However, the follow-up is short and a neuroimaging evaluation after transplantation to observe infarct lesion evolution was not performed. Moreover, a control group was not planned.

Yang et al. in 2005 [27] investigated intrathecal injection of embryonic neural stem cells (ENSCs) in 26 patients (15 
ischemic and 11 haemorrhagic); 3 patients had acute hemorrhagic stroke whereas 23 patients suffered from ischemic or haemorrhagic stroke within 3 months-30 years (mean 4.2 years). In the 3 acute patients with haematoma volume between 35 and $40 \mathrm{~mL}$ a microinvasive intracerebral haematoma puncture was performed and a suspension of ENSCs was conducted to the lesion by a drainage tube. In the other patients cells were intrathecally administered into the subarachnoidal space and flowed to the cerebral surface through CSF circulation. Patient outcome was evaluated both through instrumental data (EEG, CT; MRI) and clinical assessment, but the time of outcome evaluation is not clearly indicated. No side effects were registered except for transient fever in 4 patients. Twenty-three patients improved at ESS and at Bartel Index. However, it has to be considered that patients also underwent to physical, occupational and speech therapies and the study lacks of a control group.

We found other 6 published Chinese studies evaluating stem cells transplantation in patients with different cerebrovascular disorders [34-39]. Since only English language abstracts of these studies are available, we did not include them in this review.

Currently, 3 clinical ongoing studies are still recruiting stroke patients for stem cell therapy.

The first study, conducted in UK, is a randomized, placebo-controlled, dose-escalation pilot study aimed at determining safety, tolerability and effects on impairment, disability and dependency of an autologous CD34+ subset of bone marrow stem cell infusion into the MCA in patients who have suffered from acute total anterior circulation syndrome (TACS) [40]. The second is a phase I trial sponsored by a UK biotechnology company, evaluating the safety of transformed human neural line cells transplantation in patients with stroke [41].

The third study is conducted in Brazil. The purpose of this study is to evaluate the safety and feasibility of intraarterial injection of autologous bone marrow mononuclear cells in patients in the acute and sub-acute phase $(<7$ days after symptoms onset) of ischemic cerebral infarct in the MCA territory [42]. The results of this study are not available and the study is ongoing.

\section{DISCUSSION}

Despite some initial promising results, the potential success of transplantation in stroke, in comparison to neurodegenerative diseases, is influenced by some critical issues including anatomy, localization and size of infarct area, time of transplantation, vascular supplies, route and site of implantation and patient selection [18, 43].

First, neuronal damage induced by stroke is not selective but involves different neuronal and also glial cell populations. Moreover, stroke, also affecting white matter in addition to gray matter, can disrupt different anatomical pathways. Therefore, it would be necessary that cell sources do not have restricted fates and can differentiate into appropriate cell types in relation to ectopic site other than they should be able to produce functional connections.
The second point is the lesion site. Most experimental studies used stroke model with damage in the striatum where cells were directly delivered. Since only few authors investigated cell therapy for cortex infarcts [44-46], it is still unclear whether transplanted cells can restore cortical damage.

Third, the appropriate transplantation time after stroke is still unknown, considering that the brain environment changes over time after stroke. Excitotoxic neurotransmitters, free radicals and proinflammatory mediators are released in acute phase and cell death by apoptosis may last up to several weeks $[47,48]$. The activated inflammatory response that lead to microglial reaction together with apoptotic processes in the acute phase act as negative factors for the growth and survival of transplanted cells $[49,50]$. Otherwise, in the acute phase, cytokines and neurotrophic factors such as G-CSF [51] are also released and it has been observed that they modulate neuronal growth, angiogenesis, cell proliferation, differentiation and migration from subventricular zone [52]. In delayed transplantation the scar tissue could negatively affect cells implantation.

Another important point is the vascular support of implant site. Increased vascularisation, spontaneously induced in the penumbra area during neurological recovery, has been described to correlate with longer survival in stroke patients [53] and could represent a potential target for cell therapy [54-57]. Transplanted stem cells have been demonstrated to secrete and promote the release of endogenous factors such as Stromal Derived Factor-1 (SDF-1), Brain Derived Neurotrophic Factor (BDNF), Fibroblast Growth Factor (FGF), Vascular Endothelial Growth Factor (VEGF) and Granolocyte-Monocyte Colony-Stimulating Factor (GM-CSF), which increase angiogenesis.

Finally, the route of cell administration is another key point of stem cells transplantation. Different ways of delivery (intracerebral, intraventricular or intravenous) have been used in animal models and in stroke patients [58, 59]. Despite it has been observed that cells induce a similar recovery independently from the way of administration, intracerebral transplantation seems to be the best route. In the acute phase it could be better to inject cells into the penumbral area, where viable environment is present [60]. Alternatively, transplant delivery could be made distant from the infarct area, for instance in the contralateral side, that takes the advantage of healthy and well vascularized environment [61]. In fact some authors demonstrated that both intact and damaged hemisphere after stroke attracts grafted stem cells [62]. Intravenous administration, although less invasive, raises the question if cells target other organs than the lesion site.

The result of these small initial clinical studies included in this paper indicates that stem cell therapy may be safe and technically feasible in stroke patients. However, data are only preliminary and insufficient to assess efficacy. The results of available studies are compatible with the notion that stem cells transplantation significantly improves some functional outcomes (e.g. ESS, BI, Fugl-Meyer Assessment of motor recovery, cognitive functions, etc) in stroke patients. However, studies are not comparable for heterogeneity in term of patient populations, type of cells, timing of injection and mode of delivery. Moreover, the significance of these results is unclear considering small simple size of studies and 
lack double-blinded controls. Thus, the best experimental condition cannot be defined. Side effects were observed in 3 of 7 studies presented above $[21,23,25]$ and safety is a principal concern. Epilepsy, risk of bleeding or thrombosis at the site of injection and risk of malignant transformation are still limiting factors. Therefore, we cannot draw a definitive conclusion on the safety of stem cells transplantation. In the Kondziolka et al. [22] and Bang et al. [24] studies there was no evidence of teratoma transformation but the length of follow-up was only one year and longer-term follow-up are required to rule out the tumorigenic potential of implanted cells $[21,24]$.

Several key questions need to be answered by higher quality randomised clinical trials. Since statins have been demonstrated to improve neurological functional outcome by promoting angiogenesis, neurogenesis and synaptic plasticity in experimental studies [63-65], it could be interesting to investigate whether the concomitant administration of statins, whose tolerability and safety have been widely proven in humans [66], could influence outcome of stroke patients after stem cell transplantation.

However, although animal models differ significantly from their human counterparts, better investigation of the effects of stem cell treatment on stroke within well-designed preclinical studies could improve the quality of clinical trials.

\section{REFERENCES}

[1] The NINDS rt-PA Stroke Study Group. Tissue plasminogen activator for acute ischemic stroke. N Engl J Med 1995; 333: 1581-7.

[2] Adams HP Jr, del Zoppo G, Alberts MJ, Bhatt DL, Brass L, Furlan A, et al. American Heart Association; American Stroke Association Stroke Council; Clinical Cardiology Council; Cardiovascular Radiology and Intervention Council; Atherosclerotic Peripheral Vascular Disease and Quality of Care Outcomes in Research Interdisciplinary Working Groups. Guidelines for the early management of adults with ischemic stroke: a guideline from the American Heart Association/American Stroke Association Stroke Council, Clinical Cardiology Council, Cardiovascular Radiology and Intervention Council, and the Atherosclerotic Peripheral Vascular Disease and Quality of Care Outcomes in Research Interdisciplinary Working Groups: the American Academy of Neurology affirms the value of this guideline as an educational tool for neurologists. Stroke 2007; 38(5): 1655-711.

[3] Kaste M. Use of animal models has not contributed to development of acute stroke therapies: pro. Stroke 2005; 36: 2323-4.

[4] Lees KR, Zivin JA, Ashwood T, Davalos A, Davis SM, Diener HC, et al. NXY-059 for acute ischemic stroke. N Engl J Med 2006; 354 : 588-600.

[5] Cramer SC, Chopp M. Recovery recapitulates ontogeny. Trends Neurosci 2000; 23: 265-71.

[6] Li Y, Chopp M, Chen J, Wang L, Gautam SC, Xu YX, et al. Intrastriatal transplantation of bone marrow nonhematopoietic cells improves functional recovery after stroke in adult mice. J Cereb Blood Flow Metab 2000; 2 0: 1311-9.

[7] Zhang R, Zhang L, Zhang Z, Wang Y, Lu M, Lapointe M, et al. A nitric oxide donor induces neurogenesis and reduces functional deficits after stroke in rats. Ann Neurol 2001; 50: 602- 11.

[8] Chen J, Sanberg PR, Li Y, Wang L, Lu M, Willing AE, et al. Intravenous administration of human umbilical cord blood reduces behavioral deficits after stroke in rats. Stroke 2001; 32: 2682-8.

[9] Zhang R, Wang Y, Zhang L, Zhang Z, Tsang W, Lu M, et al. Sildenafil (Viagra) induces neurogenesis and promotes functional recovery after stroke in rats. Stroke 2002; 33: 2675-80.

[10] Chen J, Zhang ZG, Li Y, Wang Y, Wang L, Jiang H, et al. Statins induce angiogenesis, neurogenesis, and synaptogenesis after stroke. Ann Neurol 2003; 53: 743-51.

[11] Wang L, Zhang Z, Wang Y, Zhang R, Chopp M. Treatment of stroke with erythropoietin enhances neurogenesis and angiogenesis and improves neurological function in rats. Stroke 2004; 35: 17327.

[12] Zhang ZG, Jiang Q, Zhang R, Zhang L, Wang L, Arniego P, et al. Magnetic resonance imaging and neurosphere therapy of stroke in rat. Ann Neurol 2003; 53: 259 -63.

[13] Shyu WC, Lin SZ, Yang HI, Tzeng YS, Pang CY, Yen PS, et al. Functional recovery of stroke rats induced by granulocyte colonystimulating factor-stimulated stem cells. Circulation 2004; 110: 1847-54.

[14] Jin K, Sun Y, Xie L, Childs J, Mao XO, Greenberg DA. Postischemic administration of heparin-binding epidermal growth factor-like growth factor (hb-EGF) reduces infarct size and modifies neurogenesis after focal cerebral ischemia in the rat. $\mathrm{J}$ Cereb Blood Flow Metab 2004; 24: 399-408.

[15] Lindvall O, Kokaia Z. Stem cells for the treatment of neurological disorders. Nature 2006; 441: 1094-6.

[16] Piccini P, Brooks DJ, Björklund A, Gunn RN, Grasby PM, Rimoldi $\mathrm{O}$, et al. Dopamine release from nigral transplants visualized in vivo in a Parkinson's patient. Nat Neurosci 1999; 2: 1137-40.

[17] Lindvall O, Hagell P. Clinical observations after neural transplantation in Parkinson's disease. Prog Brain Res 2000; 127: 299-320.

[18] Savitz SI, Dinsmore JH, Wechsler LR, Rosenbaum DM, Caplan LR. Cell therapy for stroke. NeuroRX 2004; 1: 406-14.

[19] Chen J, Li Y, Wang L, Zhang Z, Lu D, Lu M, et al. Therapeutic benefit of intravenous administration of bone marrow stromal cells after cerebral ischemia in rats. Stroke 2001; 32: 1005-11.

[20] Wechsler LR, Kondziolka D. Cell therapy: replacement. Stroke 2003; 34: 2081-2.

[21] Kondziolka D, Wechsler L, Goldstein S, Meltzer C, Thulborn KR, Gebel J, et al. Transplantation of cultured human neuronal cells for patients with stroke. Neurology 2000; 55: 565-9.

[22] Kondziolka D, Steinberg GK, Wechsler L, Meltzer CC, Elder E, Gebel J, et al. Neurotransplantation for patients with subcortical motor stroke: a phase 2 randomized trial. J Neurosurg 2005; 103: 38-45.

[23] Savitz SI, Dinsmore J, Wu J, Henderson GV, Stieg P, Caplan LR. Neurotransplantation of fetal porcine cells in patients with basal ganglia infarcts: a preliminary safety and feasibility study. Cerebrovasc Dis 2005; 20: 101-7.

[24] Bang OY, Lee JS, Lee PH, Lee G. Autologous mesenchymal stem cell transplantation in stroke patients. Ann Neurol 2005; 57: 87482 .

[25] Rabinovich SS, Seledtsov VI, Banul NV, Poveshchenko OV, Senyukov VV, Astrakov SV, et al. Cell therapy of brain stroke. Bull Exp Biol Med 2005; 139: 126-8.

[26] Man Y, Li J, Yang B, Ma J. Vein transplantation using human umbilical cord blood stem cells in the treatment of stroke sequela. Neural Regener Res 2006; 1: 618-21.

[27] Yang QC, Zhang XD, Liang CC, Du Y, Li HW. Functional evaluation of stroke patients 6 months after intrathecal injection of neural stem cells. Chinese J Clin Rehab 2005; 9: 208-10.

[28] Pleasure SJ, Lee VM. NTera 2 cells: a human cell line which displays characteristics expected of a human committed neuronal progenitor cell. J Neurosci Res 1993; 3:585-602.

[29] Guillemain I, Alonso G, Patey G, Privat A, Chaudieu I. Human NT2 neurons express a large variety of neurotransmission phenotypes in vitro. J Comp Neurol 2000; 422:3 80-95.

[30] Borlongan CV, Saporta S, Poulos SG, Othberg A, Sanberg PR. Viability and survival of hNT neurons determine degree of functional recovery in grafted ischemic rats. Neuroreport 1998; 9: 283742.

[31] Nelson PT, Kondziolka D, Wechsler L, Goldstein S, Gebel J, De Cesare $\mathrm{S}$, et al. Clonal human (hNT) neuron grafts for stroke therapy: neuropathology in a patient 27 months after implantation Am J Pathol 2002; 160: 1201-6.

[32] Meltzer CC, Kondziolka D, Villemagne VL, Wechsler L, Goldstein $\mathrm{S}$, Thulborn KR, et al. Serial [18F] fluorodeoxyglucose positron emission tomography after human neuronal implantation for stroke. Neurosurgery. 2001; 49: 586-91.

[33] Stilley CS, Ryan CM, Kondziolka D, Bender A, DeCesare S, Wechsler L. Changes in cognitive function after neuronal cell transplantation for basal ganglia stroke. Neurology. 2004; 63: 1320-2.

[34] Zhang RY, Zheng YR, Hu SS, Cheng HB, An YH. Clinical analysis of neural stem cells for treatment of sequela in 50 stroke patients. Chinese J Clin Rehab 2006; 10: 138-9. 
[35] Liu RW, Huang Hy, Xi Ht, Chen L, Zhang F, Liu YC, et al. Embryo olfactory ensheathing cell transplantation for cerebral palsy: A result report of 4 cases 4 weeks after transplantation. J Clin Rehabil Tissue Eng Res 2007; 11: 5645-8.

[36] Li JB, Man Y, Shan H, Duan YL. Sterile preparation of umbilical cord derived mesenchymal stem cells with multiple bags: method and effect. J Clin Rehabil Tissue EngRes 2007; 11: 4781-4.

[37] Yang QC, Liang CC, Li MX, Zhang XD, Ma DF. Neural stem cell transplantation for treating stroke sequela in 59 cases. J Clin Rehabil Tissue Eng Res 2007; 11: 4033-5.

[38] Wang YC, Zhang CQ, Wang LZ, Wen H, Yin ZM. Autologous bone marrow-derived mononuclear cell transplant for treatment of nervous system damage and degenerative disease: A report of 42 cases. J Clin Rehabil Tissue Eng Res 2007; 11: 3994-7.

[39] Lin SZ, Shyu WC, Li H. CD34+ stem cell therapy in chronic stroke patients - phase I trial. Cell Transplant 2008; 17: 472.

[40] Hess DC, Borlongan CV. Cell-based therapy in ischemic stroke. Expert Rev Neurother 2008; 8:1193-201.

[41] Hess DC, Borlongan CV. Stem cells and neurological diseases. Cell Prolif 2008; 41 (Suppl 1): 94-114.

[42] Mendez-Otero R, de Freitas GR, André C, de Mendonça ML, Friedrich M, Oliveira-Filho J. Potential roles of bone marrow stem cells in stroke therapy. Regen Med 2007; 2: 417-23.

[43] Bliss T, Guzman R, Daadi M, Steinberg GK. Cell transplantation therapy for stroke. Stroke 2007; 38: 817-26.

[44] Dunnett SB, Ryan CN, Levin PD, Reynolds M, Bunch ST. Functional consequences of embryonic neocortex transplanted to rats with prefrontal cortex lesions. Behav Neurosci 1987; 101: 489-503.

[45] Gates MA, Fricker-Gates RA, Macklis JD. Reconstruction of cortical circuitry. Prog Brain Res 2000; 127: 115-56.

[46] Kesslak JP, Brown L, Steichen C, Cotman CW. Adult and embryonic frontal cortex transplants after frontal cortex ablation enhance recovery on a reinforced alternation task. Exp Neurol 1986; 94 : 615-26.

[47] Lo EH, Dalkara T, Moskowitz MA. Mechanisms, challenges and opportunities in stroke. Nat Rev Neurosci 2003; 4: 399-415.

[48] Durukan A, Tatlisumak T. Acute ischemic stroke: overview of major experimental rodent models, pathophysiology, and therapy of focal cerebral ischemia. Pharmacol Biochem Behav 2007; 87: 179-97.

[49] Li Y, Chen J, Chopp M. Cell proliferation and differentiation from ependymal, subependymal and choroid plexus cells in response to stroke in rats. J Neurol Sci 2002; 193: 137-46.

[50] Nakatomi H, Kuriu T, Okabe S, Yamamoto S, Hatano O, Kawahara $\mathrm{N}$, et al. Regeneration of hippocampal pyramidal neurons after ischemic brain injury by recruitment of endogenous neural progenitors. Cell 2002; 110: 429-41.

[51] Hess DC, Borlongan CV. Stem cells and neurological diseases. Cell Prolif 2008; 41: 94-114.
[52] Chen CP, Lee YJ, Chiu ST, Shyu WC, Lee MY, Huang SP et al. The application of stem cells in the treatment of ischemic diseases. Histol Histopathol 2006; 21: 1209-16.

[53] Krupinski J, Kaluza J, Kumar P, Kumar S, Wang JM. Role of angiogenesis in patients with cerebral ischemic stroke. Stroke 1994; 25 1794-8.

[54] Wei L, Erinjeri JP, Rovainen CM, Woolsey TA. Collateral growth and angiogenesis around cortical stroke. Stroke 2001; 32: 2179-84.

[55] Zhang ZG, Zhang L, Croll SD, Chopp M. Angiopoietin-1 reduces cerebral blood vessel leakage and ischemic lesion volume after focal cerebral embolic ischemia in mice. Neuroscience 2002; 113: 683-7.

[56] Senior K. Angiogenesis and functional recovery demonstrated after minor stroke. Lancet 2001; 358: 817.

[57] Krupinski J, Stroemer P, Slevin M, Marti E, Kumar P, Rubio F. Three-dimensional structure and survival of newly formed blood vessels after focal cerebral ischemia. Neuroreport 2003; 14: 117-6.

[58] Jin K, Sun Y, Xie L, Mao XO, Childs J, Peel A, et al. Comparison of ischemia-directed migration of neural precursor cells after intrastriatal, intraventricular, or intravenous transplantation in the rat. Neurobiol Dis 2005; 18: 366-74.

[59] Grabowski M, Sorensen JC, Mattsson B, Zimmer J, Johansson BB. Influence of an enriched environment and cortical grafting on functional outcome in brain infarcts of adult rats. Exp Neurol 1995; 133: 96-102.

[60] Hadani M, Freeman T, Munsiff A, Young W, Flamm E. Fetal cortical cells survive in focal cerebral infarct after permanent occlusion of the middle cerebral artery in adult rats. J Neurotrauma 1992; 9: 107-12.

[61] Modo M, Stroemer RP, Tang E, Patel S, Hodges H. Effects of implantation site of stem cell grafts on behavioral recovery from stroke damage. Stroke 2002; 33: 2270-8.

[62] Veizovic, T, Beech JS, Stroemer RP, Watson WP, Hodges H. Resolution of stroke deficits following contralateral grafts of conditionally immortal neuroepithelial stem cells. Stroke 2001; 32: 1012-9.

[63] Chen J, Zacharek A, Li A, Cui X, Roberts C, Lu M, et al. Atorvastatin promotes presenilin-1 expression and Notch1 activity and increases neural progenitor cell proliferation after stroke. Stroke 2008; 39: 220-6.

[64] Chen J, Chopp M. Neurorestorative treatment of stroke: cell and pharmacological approaches. NeuroRx 2006; 3: 466-73.

[65] Besler C, Doerries C, Giannotti G, Lüscher TF, Landmesser U. Pharmacological approaches to improve endothelial repair mechanisms. Expert Rev Cardiovasc Ther 2008; 6: 1071-82.

[66] Bersano A, Ballabio E, Lanfranconi S, Mazzucco S, Candelise L, Monaco S. Statins and stroke. Curr Med Chem 2008; 15: 2380-92.

Received: November 25, 2008 Revised: December 27, 2008 Accepted: January 12, 2009 